( Т. Ю. Киричок, д-р техн. наук, професор, Н. Л. Талімонова, канд. техн. наук, доцент, КП। ім. Ігоря Сікорського, Київ, Україна

\title{
РОЗРОБКА СИСТЕМИ ОЦІНКИ СТАНУ ЗБЕРЕЖЕНОСТІ ФОНДІВ РІДКІСНИХ ТА ЦІННИХ ВИДАНЬ
}

\begin{abstract}
Розроблено класифікацію основних видів пошкодження книжкових видань; проведено оцінювання стану збереженості видань фонду рідкісних і цінних видань науковотехнічної бібліотеки «Київського політехнічного інституту імені Ігоря Сікорського", випущених до 1850 року.
\end{abstract}

Ключові слова: фоксинги; згасання тексту; пошкодження паперу; мікологічні ураження; ганчірковий папір; деструкція палітурного матеріалу; зміна кольору.

\section{Постановка проблеми}

Фонд рідкісних і цінних видань науково-технічної бібліотеки ім. Г.І.Денисенка Національного технічного університету України «Київський політехнічний інститут імені Ігоря Сікорського» зберігає багато книжкових пам'яток, що яскраво відображають історію розвитку вітчизняної та зарубіжної науки і техніки. Стан їх збереженості в першу чергу залежить від якості та композиційного складу матеріальної основи книг, а також умов зберігання.

Негативні фактори, що впливають на фізичний стан видань, зумовлюють їх пошкодження та появу дефектів. Залежно від їх наявності, можна з'ясувати причину їх появи та вжити заходів для подолання процесів подальшого погіршення стану видань та спланувати заходи щодо їх консервації та реставрації.

Аналіз наукових робіт, що стосуються методів та засобів забезпечення збереженості старовин- них видань, показав, що праці науковців направлені на дослідження явищ деструкції паперової основи, ділянок паперу з наявними фоксингами та мікологічними ураженнями різними методами [1-5]. Комплексну систему оцінювання збереженості видань наводять лише у методичних рекомендаціях архівних установ та бібліотек, але запропоновані методи не мають достеменного розмежування пошкоджень, що притаманні для паперу блоку, покривного матеріалу палітурки, ниток та інших елементів книги [6, 7].

\section{Мета роботи}

Розробка класифікації основних видів пошкодження, що притаманні окремим частинам видання та проведення оцінювання стану збереженості видань фонду, випущених до 1850 року, що дозволить виявити найбільш типові види пошкоджень та спланувати заходи консервації та реставрації. 


\section{Аналіз попередніх досліджень}

На пошкодження бібліотечних фондів вливає низка факторів. Недотримання режимів зберігання, зокрема, підвищена вологість та температура повітря може призвести до біологічного ураження пліснявими грибами; дія світла (особливо сонячного) згубно впливає на паперову основу, пришвидшує її природне старіння, що супроводжується жовтінням та підвищенням ламкості паперу.

Суттєвий вплив має інтенсивність користування виданням, що супроводжується забрудненням від рук читача (особливо в нижньому правому кутку на перших сторінках), потертістю, руйнуванням корінця книги.

Копіювання та сканування також негативно впливає на фізико-механічні властивості основи, оскільки видання піддається впливу ультрафіолетового випромінювання. Окремим питанням постає свідоме пошкодження матеріальної основи книги [2, 4, 6, 8-10].

Залежно від причин появи пошкодження, їх поділяють на механічні, фізико-хімічні, біологічні; окремо розглядають пошкодження, спричинені водою та вогнем в аварійних ситуаціях.

Пошкодження механічної етіології - це порушення цілісності паперу при механічній дії на нього, що призводить до розривів полотна, появи надривів, вищипів, зморшок, згинів, тріщин, потертостей, втрати частин аркуша, закручування та пошкодження паперу на краях аркуша тощо. Дефекти механічного походження легко ідентифікувати під час візуального перегляду. При збіль- шенні кількості таких дефектів зростає ступінь їх сумарної небезпеки для цілісності та міцності носія. До пошкоджень цієї групи відносять також відрив палітурки від блоку, пошкодження її матеріалу, випадіння зошитів блоку [6]. Також сюди відносять вандалізм - виривання сторінок або частин видання.

Пошкодження фізико-хімічної етіології - це порушення цілісності паперу внаслідок хімічних реакцій, що відбуваються під час природного старіння носія. Воно спричинене кількома речовинами. Такі пошкодження супроводжуються появою крихкості, жовтінням чи бурінням кольору основи по всьому аркушу або в окремих його частинах, локальних пошкоджень від потрапляння різних речовин. Найпоширенішими дефектами паперу хімічного походження є фоксинги - дефекти у вигляді плям різної форми та розмірів, колір яких може змінюватися від жовтувато-коричневих до темно-коричневих. Дія води призводить до перезволоження паперу, його намокання, злипання аркушів, появи розмитих ореолів по всьому аркушу, зсукування аркушів при висиханні [9].

Пошкодження біологічної етіології - це часткове або повне порушення цілісності паперу біологічними агентами (мікроорганізмами, комахами, гризунами). Частину дефектів цієї групи легко візуалізувати: наскрізні круглі або овальні отвори, візерунки ходів («мереживо»), проїдені фрагменти шкіри, паперу комахами або гризунами, наявність загиблих комах, продуктів їх життєдіяльності, бурового борошна тощо. Важче ідентифікуються ураження, 


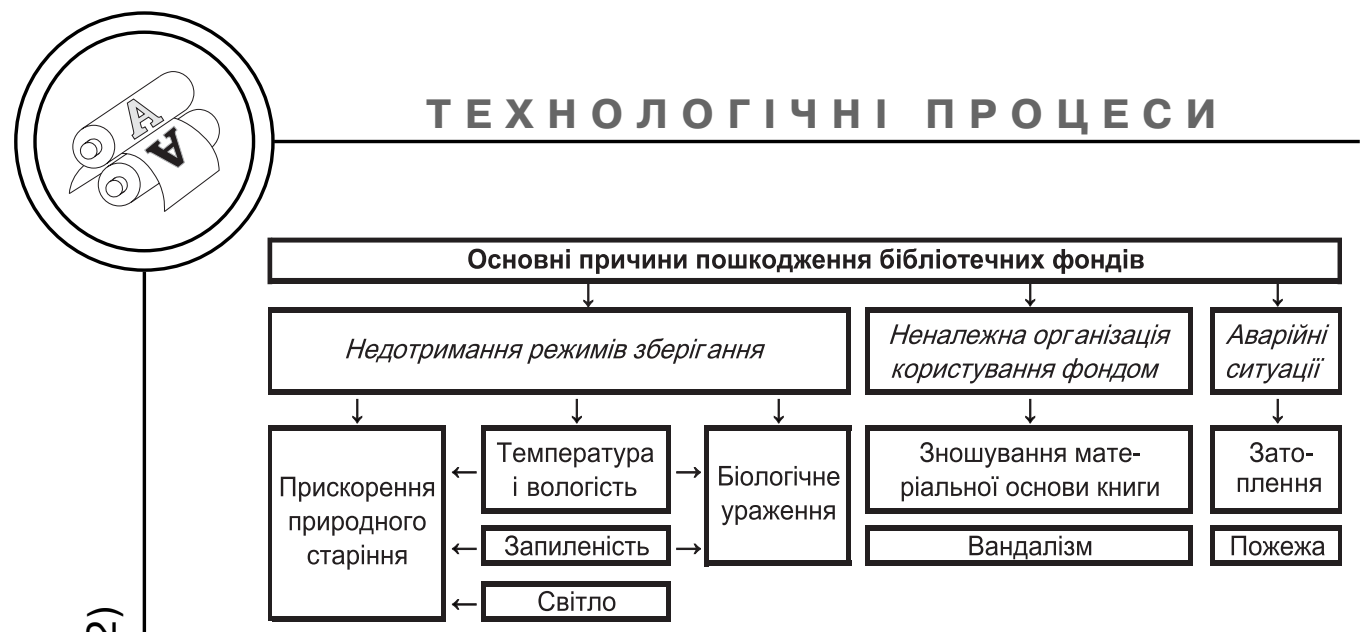

Рис. 1. Основні причини пошкодження бібліотечних фондів

спричинені плісеневими грибами, розпізнати які можливо за локально ослабленими, зруйнованими частинами основи, чорним або кольоровим порошком спор, тонкими, ватоподібними слідами міцелію, слідами намокання паперу в таких місцях [11].

\section{Результати проведених досліджень}

До основних причин пошкодження бібліотечних фондів можна віднести: недотримання режимів зберігання, неналежну організацію користуванням фонду та аварійні ситуації. На основі джерел [2, 4, 6, 8-10] ми систематизували основні причини, які спричиняють пошкодження бібліотечних фондів (рис. 1).

На основі джерел $[6,7,9,11]$ ми класифікували та систематизували основні види пошкоджень (рис. 2). Відповідно до запропонованої класифікації, розроблено систему та проведено оцінювання стану збереженості видань фон-

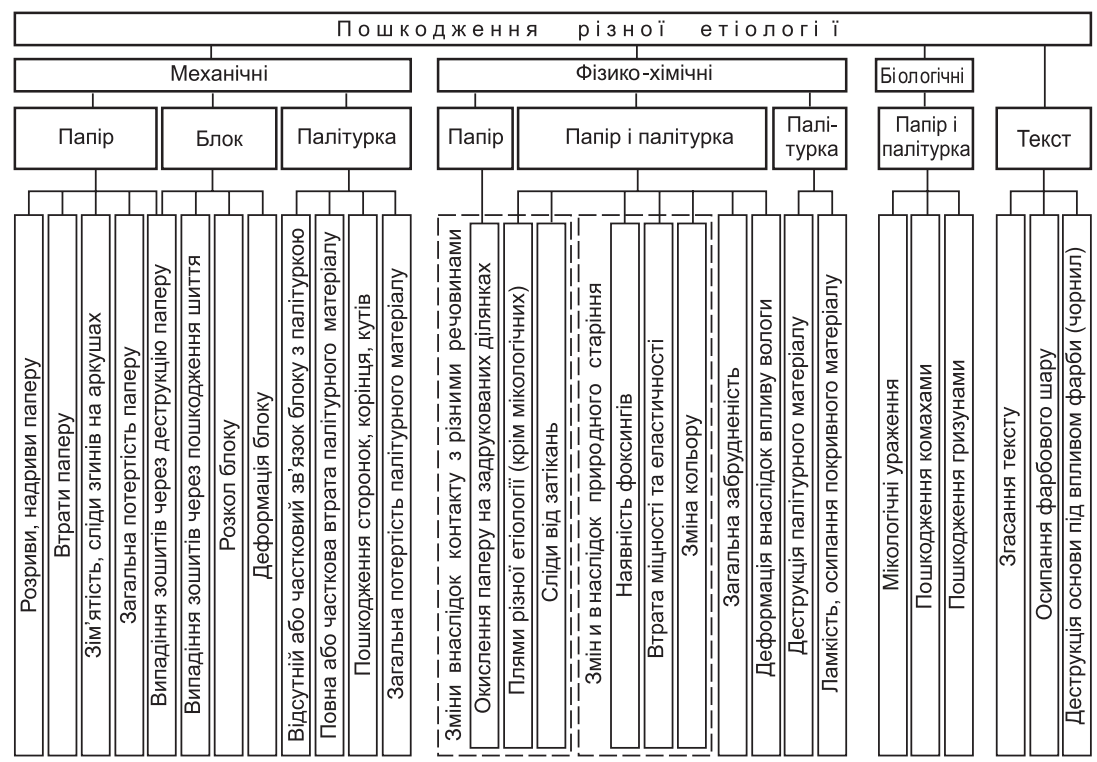

Рис. 2. Класифікація видів пошкодження видань 
ду, яка містить аналіз збереженості паперу та конструкції блоку, палітурки, текстово-ілюстративної інформації. Запропонована система ґрунтується на виділених класифікаційних ознаках і включає в себе створення оглядових карт із наявними пошкодженнями.

Для проведення оцінювання обрано книги, видані до 1850 року, що мають за основу папір різного складу та палітурки, вкриті різними видами матеріалів (табл. 1).

Книги, створені до кінця XVIII ст., виготовляли переважно на ганчірковому папері ручного виробництва, що має високу природну міцність та стійкість до старіння, й відповідно високу потенційну довговічність. Ручний спосіб виготовлення такого паперу не пошкоджував волокон природного біополімеру (целюлози), не потребував застосування тепла та хімічних речовин. Наприкінці XVIII ст. до складу ганчіркового паперу ввели невелику кількість соломи, механічно подрібнену деревину. Із середини XIX ст. папір почали виготовляти з деревної маси. Оскільки волокна целюло- зи в деревині коротші ніж волокна бавовни, льону тощо, вони мають значно меншу механічну міцність, а велика кількість лігніну прискорює процес старіння [10,6].

Оцінювання фізичного стану фонду проводилося вибірковим методом, коли для поаркушного перегляду з масиву вибирають лише його частину, що дозволяє отримати узагальнену інформацію по масиву вибірки в цілому. Вибірка склала 20 \% від загальної кількості видань фонду, що надруковані до 1850 року.

Оцінювання проводилося за п'ятибальною шкалою: 0 - відсутність пошкоджень; 1 - незначні пошкодження; 2 - середній ступінь пошкодження; 3 - високий ступінь пошкодження; 4 - максимальний ступінь пошкодження. Було застосовано метод експертних оцінок із залученням восьми експертів [12].

Проведення оцінювання збереженості видань фонду ґрунтувалося на виділених класифікаційних ознаках. Результати оцінювання наведені в табл. 2.

Таблиця 1

Обрані видання фонду

\begin{tabular}{|c|c|c|c|c|}
\hline $\begin{array}{l}\text { № } \\
\Pi / \Pi\end{array}$ & Назва, країна & $\begin{array}{l}\text { Рік ви- } \\
\text { дання }\end{array}$ & $\begin{array}{l}\text { Вид паперу } \\
\text { блоку }\end{array}$ & Матеріал палітурки \\
\hline 1 & Chimie Appliquee aux Arts & 1807 & Ганчірковий & $\begin{array}{l}\text { Корінець - шкіра, сторон- } \\
\text { ки - мармуровий папір }\end{array}$ \\
\hline 2 & $\begin{array}{c}\text { «Руководство к устрой- } \\
\text { ству потолков и стропил», } \\
\text { Росія }\end{array}$ & 1848 & $\left|\begin{array}{c}\text { Ганчірковий з до- } \\
\text { даванням дерев- } \\
\text { них волокон }\end{array}\right|$ & Папір \\
\hline 3 & $\begin{array}{c}\text { «Курс практической } \\
\text { механики», Росія }\end{array}$ & 1837 & $\begin{array}{c}3 \text { деревних } \\
\text { волокон }\end{array}$ & $\begin{array}{c}\text { Корінець - шкіра, сторон- } \\
\text { ки - мармуровий папір }\end{array}$ \\
\hline 4 & $\begin{array}{c}\text { «Gefammelte Werfe», } \\
\text { Німеччина }\end{array}$ & 1841 & $\begin{array}{c}3 \text { деревних } \\
\text { волокон }\end{array}$ & Тканина \\
\hline 5 & $\begin{array}{l}\text { «Elementa Chemiae» } \\
\text { том 1, Нідерланди }\end{array}$ & 1732 & Ганчірковий & Пергамент \\
\hline 6 & $\begin{array}{c}\text { «Traite Elementaire } \\
\text { Astronomie Physique», } \\
\text { Франція }\end{array}$ & 1811 & $\mid \begin{array}{c}\text { Ганчірковий з до- } \\
\text { даванням дерев- } \\
\text { них волокон }\end{array}$ & Шкіра \\
\hline
\end{tabular}


Закінчення табл. 1

\begin{tabular}{|c|c|c|c|c|c|}
\hline & $\begin{array}{l}\text { № } \\
\text { п/п }\end{array}$ & Назва, країна & $\begin{array}{l}\text { Рік ви- } \\
\text { дання }\end{array}$ & $\begin{array}{l}\text { Вид паперу } \\
\text { блоку }\end{array}$ & Матеріал палітурки \\
\hline & 7 & $\begin{array}{l}\text { «Annales Encyclo- } \\
\text { pediques», Франція }\end{array}$ & 1817 & Ганчірковий & $\begin{array}{c}\text { Корінець - шкіра, сторон- } \\
\text { ки - мармуровий папір }\end{array}$ \\
\hline & 8 & $\begin{array}{c}\text { «Oeuvres de Turgot», } \\
\text { Франція }\end{array}$ & 1844 & $\mid \begin{array}{c}\text { Ганчірковий з до- } \\
\text { даванням дерев- } \\
\text { них волокон }\end{array}$ & $\begin{array}{l}\text { Корінець - шкіра, } \\
\text { сторонки - тканина }\end{array}$ \\
\hline & 9 & «Worterbuch», Німеччина & 1844 & $\begin{array}{c}3 \text { деревних } \\
\text { волокон }\end{array}$ & $\begin{array}{c}\text { Корінець - шкіра, сторон- } \\
\text { ки - мармуровий папір }\end{array}$ \\
\hline 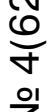 & 10 & $\begin{array}{l}\text { «Основанія дифферен- } \\
\text { ціальнаго и интеграль- } \\
\text { наго изчисления», Росія }\end{array}$ & 1829 & $\mid \begin{array}{c}\text { Ганчірковий з до- } \\
\text { даванням дерев- } \\
\text { них волокон }\end{array}$ & $\begin{array}{l}\text { Корінець - шкіра, сторон- } \\
\text { ки - мармуровий папір }\end{array}$ \\
\hline$\frac{\infty}{\infty}$ & 11 & $\begin{array}{c}\text { «Introduction a L'Analyse } \\
\text { Infinitet Simale at } \\
\text { Mathematique», Франція }\end{array}$ & 1835 & Ганчірковий & $\begin{array}{l}\text { Корінець - шкіра, } \\
\text { сторонки - тканина }\end{array}$ \\
\hline ণ্் & 12 & $\begin{array}{c}\text { «Traite de Physique experi- } \\
\text { mentale», Франція }\end{array}$ & 1816 & Ганчірковий & $\begin{array}{c}\text { Корінець - шкіра, сторон- } \\
\text { ки - мармуровий папір }\end{array}$ \\
\hline$\frac{\bar{c}}{\text { ত̃ }}$ & 13 & $\begin{array}{c}\text { «Histoire Philosophique des } \\
\text { Progress de la Physique», } \\
\text { Франція }\end{array}$ & 1812 & Ганчірковий & $\begin{array}{l}\text { Корінець - шкіра, сторон- } \\
\text { ки - мармуровий папір }\end{array}$ \\
\hline 믐 & 14 & $\begin{array}{c}\text { «Sïd-Ural-Gebirges», } \\
\text { Німеччина }\end{array}$ & 1831 & Ганчірковий & $\begin{array}{c}\text { Корінець - шкіра, сторон- } \\
\text { ки - мармуровий папір }\end{array}$ \\
\hline . & 15 & $\begin{array}{c}\text { «Физическая картина } \\
\text { Европы», Україна }\end{array}$ & 1835 & $\left|\begin{array}{c}\text { Ганчірковий з до- } \\
\text { даванням дерев- } \\
\text { них волокон }\end{array}\right|$ & $\begin{array}{c}\text { Корінець - шкіра, сторон- } \\
\text { ки - мармуровий папір }\end{array}$ \\
\hline$\frac{\mathfrak{r}}{\cdot \frac{\pi}{\square}}$ & 16 & $\begin{array}{c}\text { «Dictionnaire Tecnologique } \\
\text { Nouveau Dictionnaire } \\
\text { Universel Des Arts et } \\
\text { Metiers», Франція }\end{array}$ & 1822 & Ганчірковий & $\begin{array}{c}\text { Корінець - шкіра, сторон- } \\
\text { ки - мармуровий папір }\end{array}$ \\
\hline$\stackrel{0}{1}$ & 17 & $\begin{array}{l}\text { «Gefchichte der Chemic», } \\
\text { Німеччина }\end{array}$ & 1844 & $\begin{array}{l}3 \text { деревних } \\
\text { волокон }\end{array}$ & $\begin{array}{c}\text { Корінець - шкіра, сторон- } \\
\text { ки - мармуровий папір }\end{array}$ \\
\hline$r$ & 18 & $\begin{array}{l}\text { «Elementa Chemiae» } \\
\text { том 2, Нідерланди }\end{array}$ & 1732 & Ганчірковий & Пергамент \\
\hline ֻ้ & 19 & $\begin{array}{c}\text { "Architecture Hydraulique», } \\
\text { Франція }\end{array}$ & 1819 & Ганчірковий & $\begin{array}{c}\text { Корінець - шкіра, сторон- } \\
\text { ки - мармуровий папір }\end{array}$ \\
\hline$\stackrel{N}{N}$ & 20 & $\begin{array}{l}\text { «Experiences sur Les } \\
\text { Turbines», Німеччина }\end{array}$ & 1838 & $\mid \begin{array}{c}\text { Ганчірковий з до- } \\
\text { даванням дерев- } \\
\text { них волокон }\end{array}$ & $\begin{array}{c}\text { Корінець - тканина, сторон- } \\
\text { ки - мармуровий папір }\end{array}$ \\
\hline$\underset{\mathcal{S}}{Z}$ & 21 & $\begin{array}{c}\text { «Machines Locomotives», } \\
\text { Бельгія }\end{array}$ & 1844 & $\begin{array}{c}3 \text { деревних } \\
\text { волокон }\end{array}$ & $\begin{array}{c}\text { Корінець - шкіра, сторон- } \\
\text { ки - мармуровий папір }\end{array}$ \\
\hline & 22 & $\begin{array}{c}\text { «Dessin des Machines», } \\
\text { Франція }\end{array}$ & 1838 & $\begin{array}{c}3 \text { деревних } \\
\text { волокон }\end{array}$ & $\begin{array}{l}\text { Корінець - шкіра, } \\
\text { сторонки -папір }\end{array}$ \\
\hline & 23 & $\begin{array}{c}\text { «Cours de Mecanique», } \\
\text { Франція }\end{array}$ & 1847 & $\begin{array}{c}3 \text { деревних } \\
\text { волокон }\end{array}$ & $\begin{array}{c}\text { Корінець - шкіра, сторон- } \\
\text { ки - мармуровий папір }\end{array}$ \\
\hline & 24 & $\begin{array}{l}\text { «Traite des Machinesa } \\
\text { Vapeur», Франція }\end{array}$ & 1847 & $\mid \begin{array}{c}\text { Ганчірковий з до- } \\
\text { даванням дерев- } \\
\text { них волокон }\end{array}$ & $\begin{array}{l}\text { Корінець - тканина, } \\
\text { сторонки - папір }\end{array}$ \\
\hline & 25 & $\begin{array}{l}\text { «Ludwig Borne's gefam- } \\
\text { melte Criften», Німеччина }\end{array}$ & 1830 & $\begin{array}{c}3 \text { деревних } \\
\text { волокон }\end{array}$ & Тканина \\
\hline
\end{tabular}




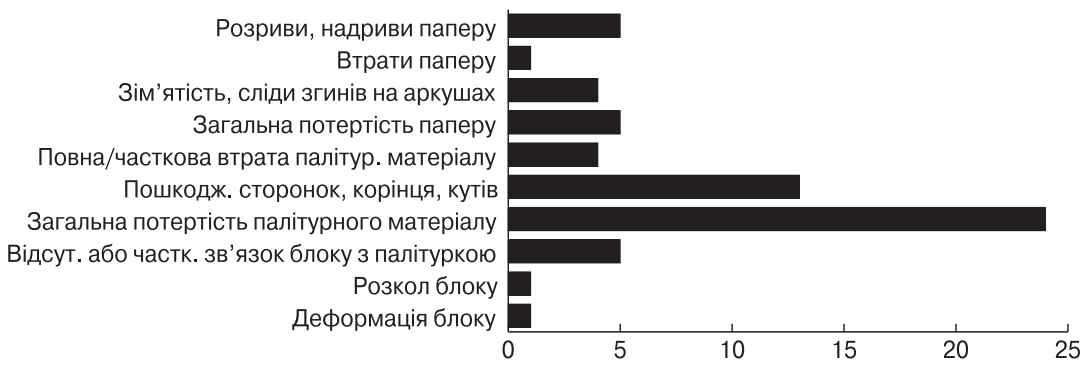

Рис. 3. Кількість книг з наявними механічними пошкодженнями паперу, блоку та палітурки

За результатами проведеного аналізу було виявлено, що пошкодження механічної етіології переважно вражають конструктивні елементи палітурок, що пояснюється більшим механічним впливом на них під час користування. Більшість книжок, що підлягали оцінюванню, мають потертість покривного матеріалу; половина видань - пошкодження сторонок, корінця та кутів (рис. 3).

Фізико-хімічні пошкодження переважають на папері як результат природного старіння та окислення, що проявляється у вигляді фоксингів (рис. 4), зміні кольору, крихкості (рис. 5). Пошкодження тієї ж етіології на палітурках проявляється як втрата міцності та деструкція палітурного матеріалу (рис. 6).
Виявлено значно менше пошкоджень біологічного походження. Три книги мають палітурки із незначними пошкодженнями комахами. Мікологічні ураження паперу та палітурок спостерігалися лише на кількох виданнях, але такий вид ураження потребує ретельного контролю. Оскільки спори грибів зберігають свою життєздатність дуже довго і стійкі до низьких й високих температур, підвищення вологості у приміщенні фонду може стати поштовхом для поширення грибкових уражень на матеріальній основі книги.

Чіткість тексту та ілюстрацій добре збереглася для всіх видань вибірки, однак в кількох книгах спостерігається зміна кольору основи, викликана впливом фарби, що говорить про окислення

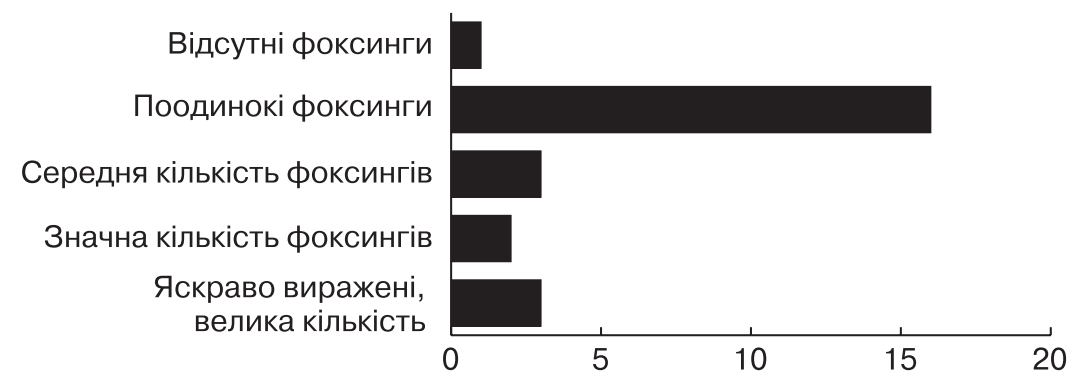

Рис. 4. Різні ступені проявлення фоксингів у книжках 


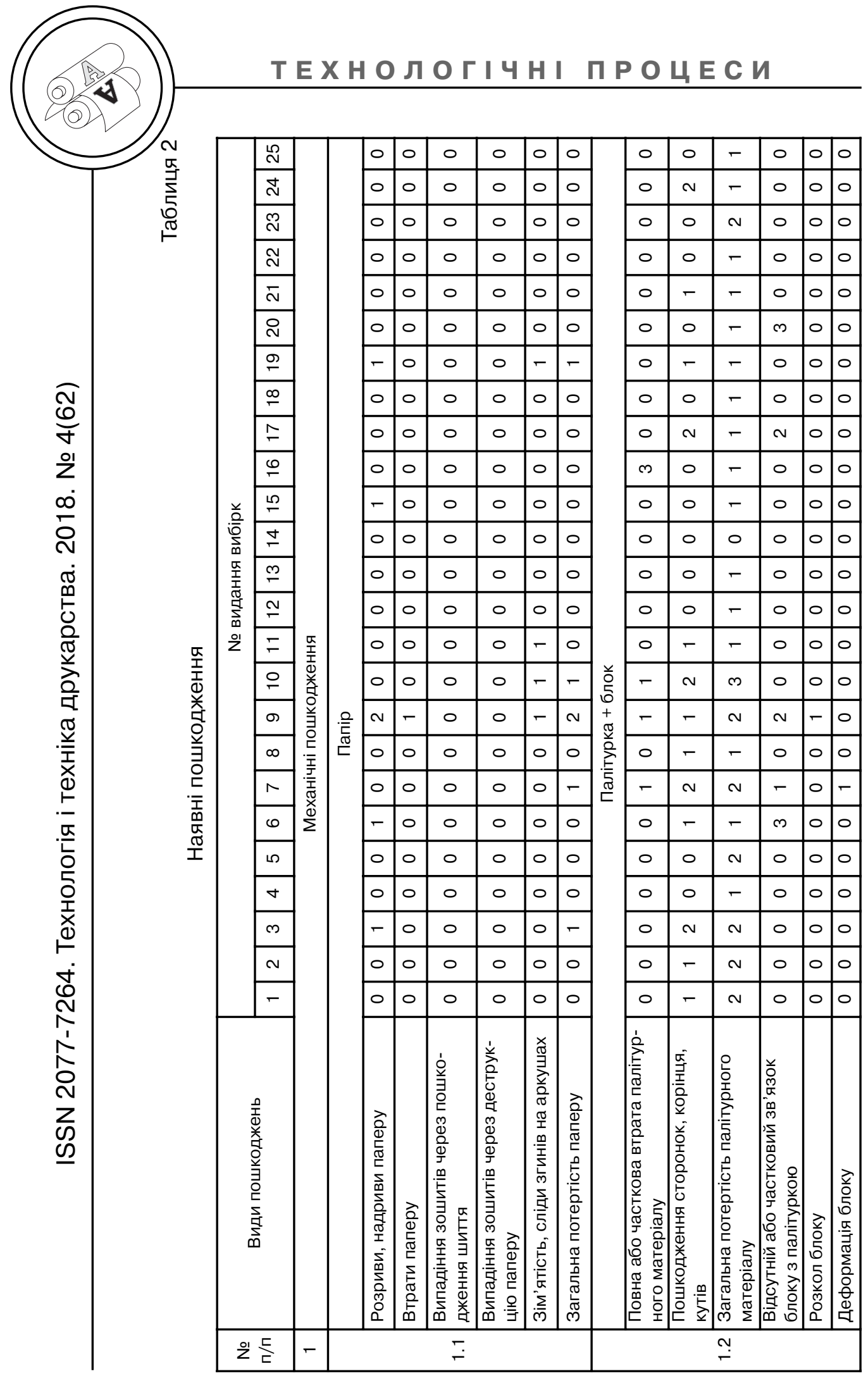




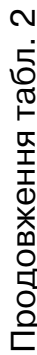

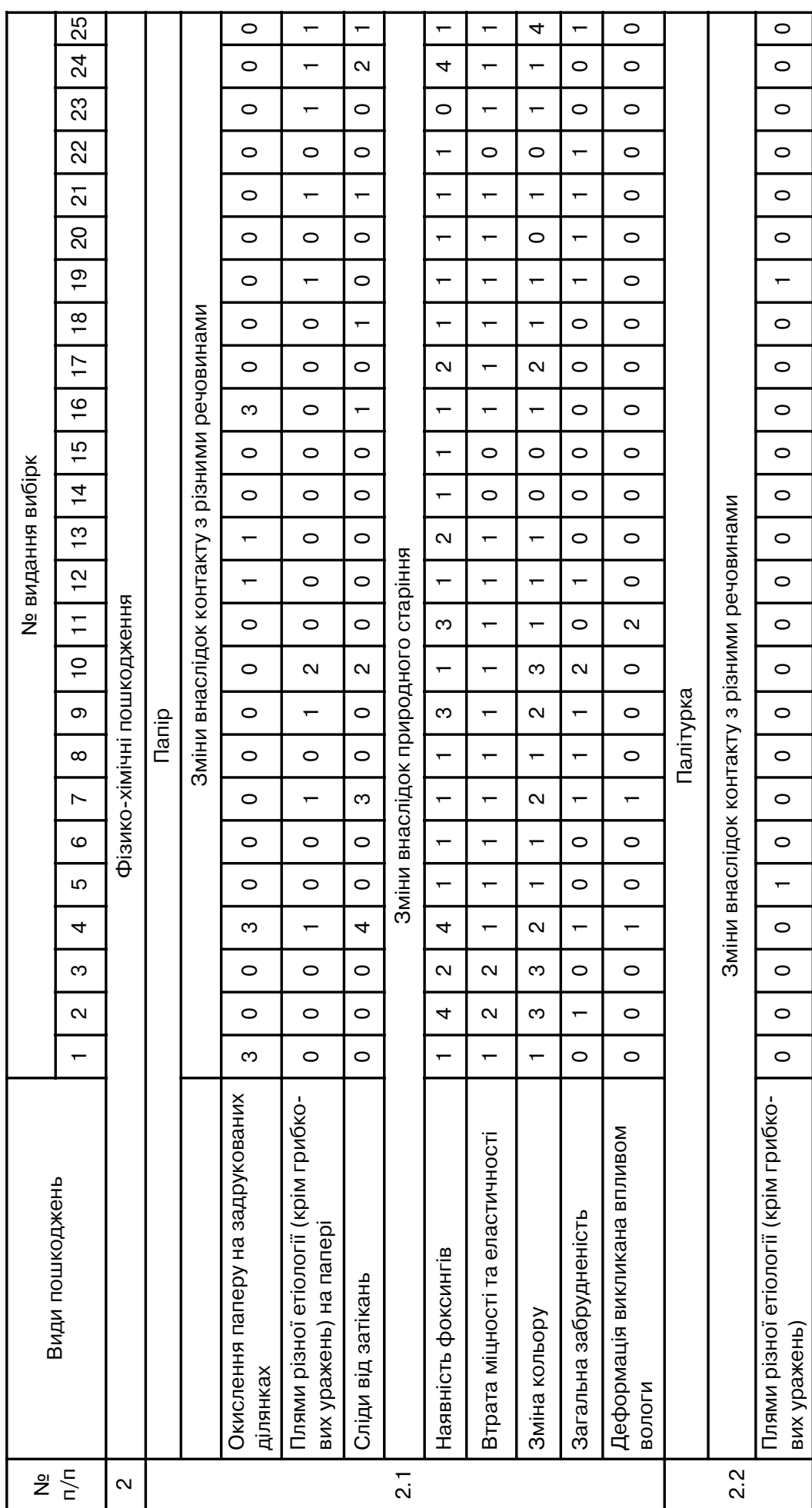




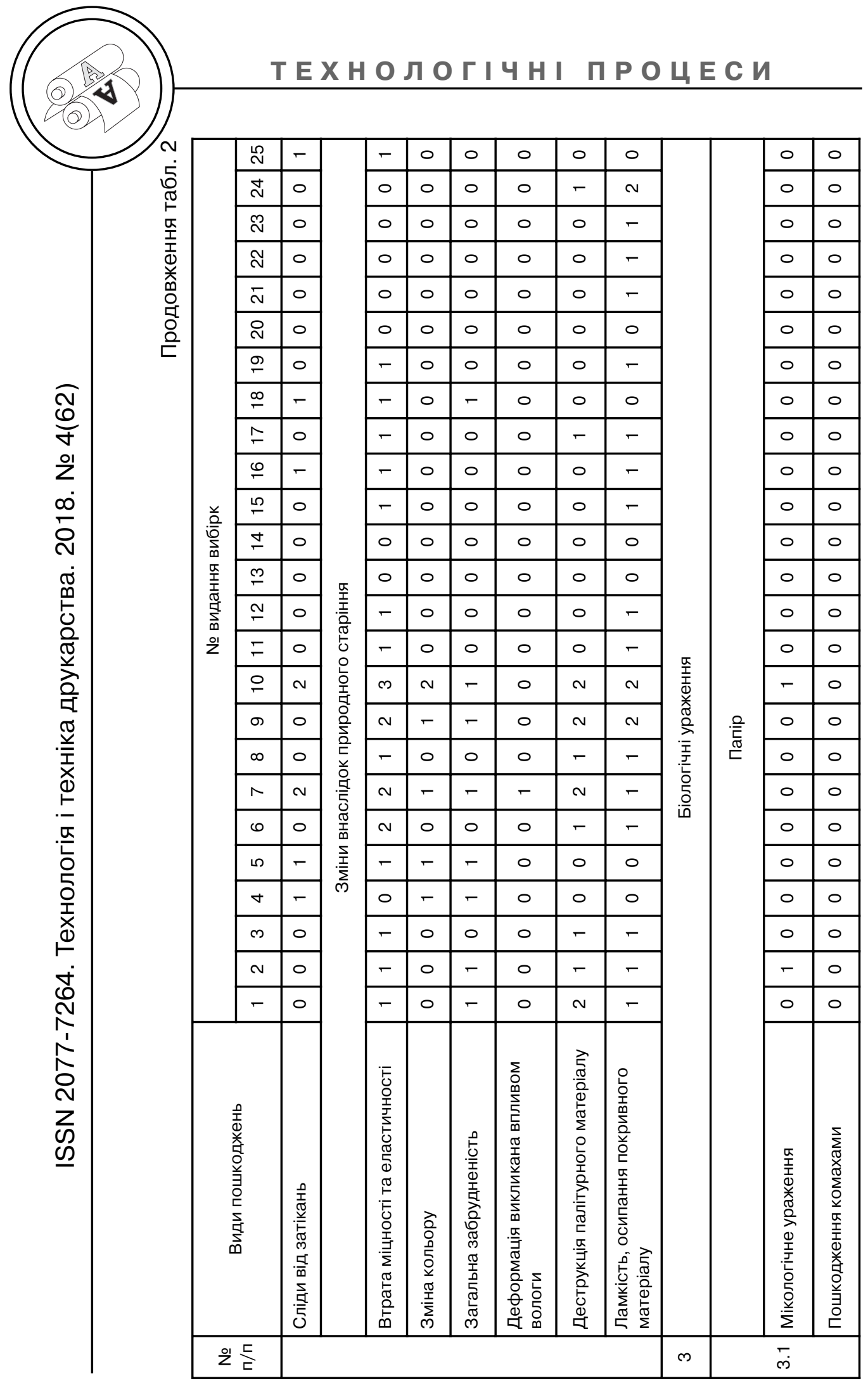


ТЕХНО ЛОГ Ч Н І ПРО ЦЕ С И

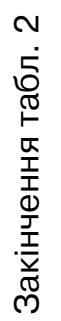

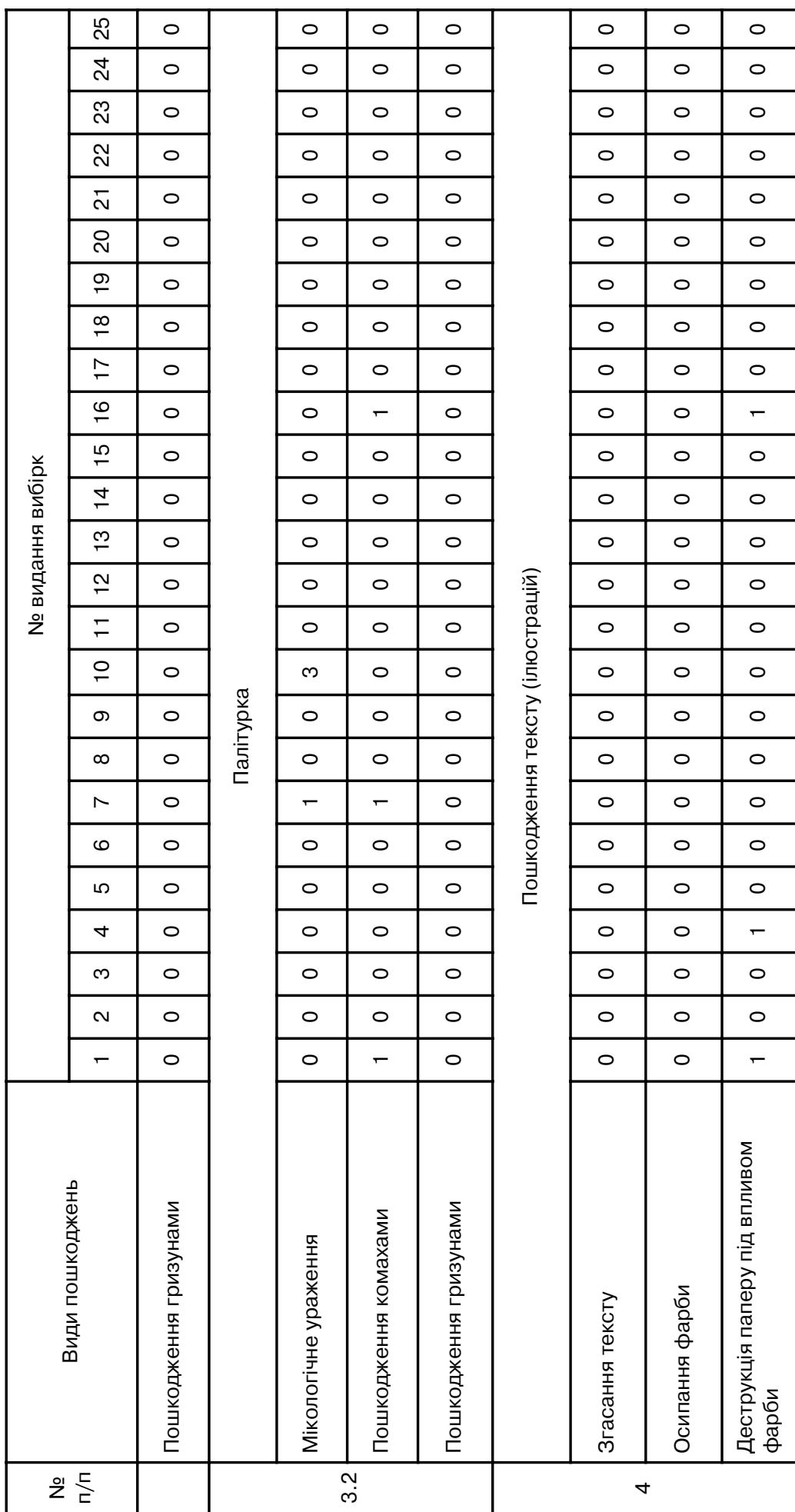




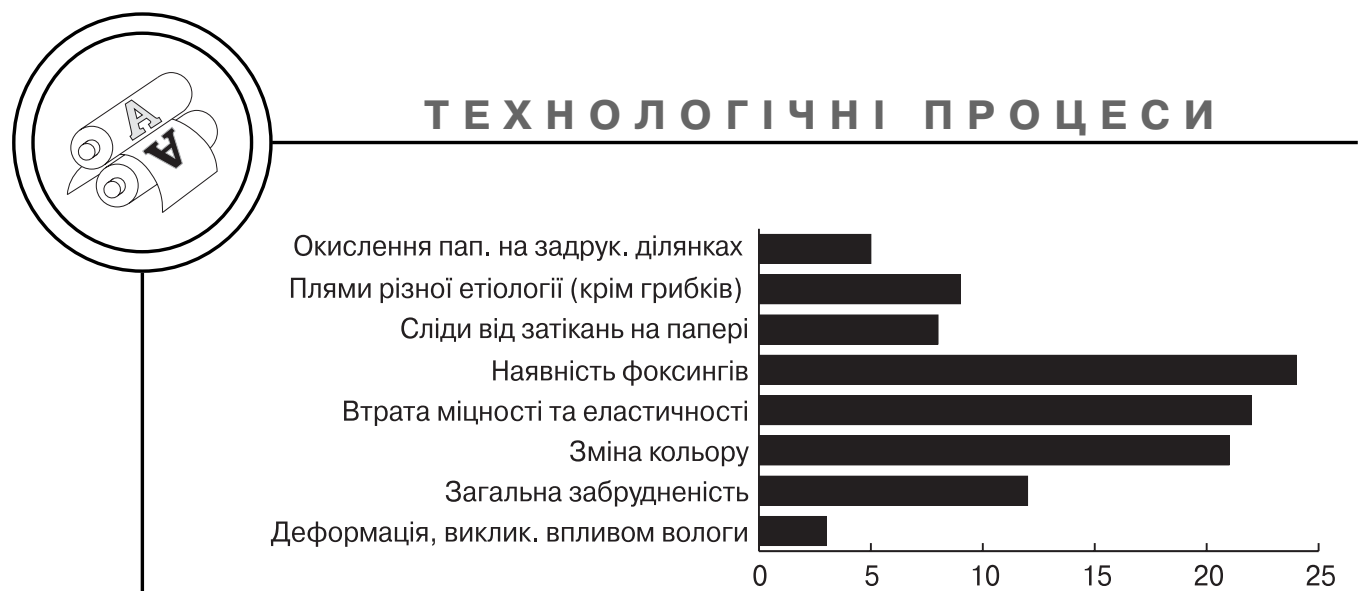

Рис. 5. Кількість книг з наявними фізико-хімічними пошкодженнями паперу

паперу на ділянках тексту. Це може бути пов'язано із особливостями рецептури використаної для друку фарби.

\section{Висновки}

За результатами проведеної оцінки стану збереженості видань фонду, випущених до 1850 року, було виявлено, що серед пошкоджень механічної етіології переважає потертість покривного матеріалу та пошкодження сторонок, корінця та кутів. Фізико-хімічні пошкодження переважають на папері як результат природного старіння та окислення, що проявляється у вигляді фоксингів, зміні кольору, крихкості. Пошкодження тієї ж етіології на палітурках проявляється як втрата міцності та деструкція палітурного матеріалу. Значно менше виявлено пошкоджень біологічного походження. Чіткість тексту та ілюстрацій добре збереглася для всіх видань вибірки.

Пошкодження різних видів та інтенсивності можуть бути зумовлені низкою факторів. Невідомо, в яких умовах зберігалося те чи інше видання до надходження до бібліотеки. Можна лише припустити, що книги з мікологічними ураженнями зберігалися у неналежних умовах 3 підвищеною вологістю повітря, видання, що мають велику кількість механічних пошкоджень активно використовувалися читачами.

Плануючи заходи із реставрації та консервації в першу чергу необхідно приділяти увагу виданням із грибковими ураженнями та великою кількістю

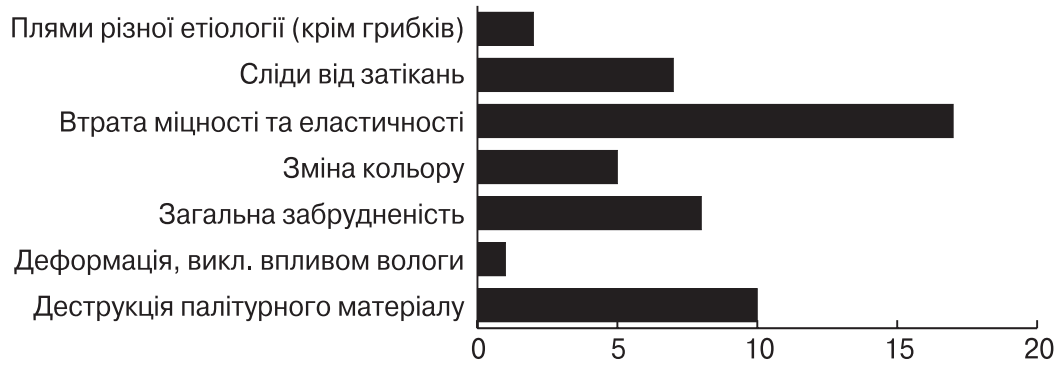

Рис. 6. Кількість книг з наявними фізико-хімічними пошкодженнями палітурки 
фоксингів. Першим необхідна спеціальна обробка для знищення грибкових спор, другим - стабілізація паперу з метою зниження його кислотності.

Розроблена класифікація та систематизація основних видів пошкоджень різного походження, що притаманні для окремих частин видання, дозволяє більш ґрунтовно здійснювати оцінювання збереженості паперу та конструкції блоку, палітурки, текстово-ілюстративної інформації.

В майбутньому планується дослідити зміну кольору та кислотності паперу, а також інтенсивність прояву фоксингів під впливом ультрафіолетового випромінювання.

\section{Список використаної літератури}

1. Missori M. Optical reflectance spectroscopy of ancient papers with discoloration or foxing / M. Missori, M. Righini, S. Selci // Optics Communications. Volume 231. Issues 1-6. 2004. pp. 99-106. [Електронний ресурс]. Режим доступу: http://doi.org/10.1016/j.optcom.2003.12.034.

2. Ребрикова Н. Л. Современные представления о происхождении фоксингов и перспективы профилактики их появления / Н. Л. Ребрикова, Н. В. Мантуровская // Материалы I науч.-практ. конф. «Консервация и реставрация музейных ценностей: Объекты на бумаге и пергаменте», 21-23 нояб. 2002. Москва. С. 27-31.

3. Missori M. Using optical spectroscopy for the study of paper degradation / M. Missori, M. Righini // Gazette du livre médiéval. 2006. № 49. pp. 25-35.

4. Mallamace1 D. NMR investigation of degradation processes of ancient and modern paper at different hydration levels / D. Mallamace1, S. Vasi, M. Missori // Frontiers of Physics. Volume 13. Issues 1. 2018. [Електронний ресурс]. Режим доступу: http://doi.org/10.1007/s11467-017-0686-6.

5. Бангровска A. Microbial assessment of the conservation status of selected library collections from Jasna Gora library in Czestochowa / А. Бангровска // Вісник Львівського університету. Серія книгозн. бібліот. та інф. технол. 2015. № 10. С. 63-69.

6. Методика оцінювання фізичного стану документів: метод. рекомендації / уклад.: А. Майстренко, Н. Мурашко, Н. Христова. К.: Держ. архів. служба України, УНДІАСД, 2013. 108 с.

7. Оценка физического состояния документов / составитель: О. В. Манернова. Томск: Региональный центр реставрации и консервации документов Научной библиотеки Томского государственного университета, 2010. 11 с.

8. Комаренко Е. И. Влияние особенностей режима хранения на памятники на бумажной основе / Е. И. Комаренко // Материалы IV Международной науч.-практ. конф. «Консервация памятников культуры в единстве и многообразии», 21-24 окт. 2003, СПб. С. 28-31.

9. Васильєва Н. А. Основные факторы сохранности библиотечного фонда / Н. А. Васильева // Материалы V Всерос. науч.-практ. конф. «Современные библиотеки в инновационном образовательном процессе», 16-17 окт. 2003, Тюмень: Издательство Тюмен. гос. университета, 2004. С. 80-83.

10. Галабурда А. Причини руйнування паперу періодичних видань другої половини XIX-початку XX ст. і методи їх консервації / А. Галабурда // Вісник Львівського університету. Серія книгозн. бібліот. та інф. технол. Львів. 2015. № 10. С. $70-77$.

11. Митрофанова С. В. Учет библиотечных фондов: практическое пособие / С. В. Митрофанова. М.: Межрегиональный центр библиотечного сотрудничества, 2005. 272 с. 
12. Орлов А. И. Экспертные оценки: Учебное пособие / А. И. Орлов. М.: ИВСТЭ, 2002. $31 \mathrm{c}$.

\section{References}

1. Missori, M. \& Righini, M. \& Selci, S. (2004). Optical reflectance spectroscopy of ancient papers with discoloration or foxing. Journal of Optics Communications, Volume 231, Issues 1-6, 99-106. Retrieved from http://doi.org/10.1016/i.optcom.2003.12.034 [in English].

2. Rebrikova, N. L. \& Manturovskaya, N. V. (2002). Sovremennye predstavleniya o proiskhozhdenii foksingov i perspektivy profilaktiki ikh poyavleniya. Journal of Materialy I nauch.-prakt. konf. 'Konservatsiya i restavratsiya muzeynykh tsennostey: Ob'ekty na bumage i pergamente', 27-31 [in Russian].

3. Missori, M. \& Righini, M. (2006). Using optical spectroscopy for the study of paper degradation. Journal of Gazette du livre médiéval, 49, 25-35 [in English].

4. Mallamace1, D. \& Vasi, S. \& Missori, M. (2018). NMR investigation of degradation processes of ancient and modern paper at different hydration levels. Journal of Frontiers of Physics, Volume 13, Issues 1. Retrieved from http://doi.org/10.1007/s11467-017-0686-6 [in English].

5. Banhrovska, A. (2015). Microbial assessment of the conservation status of selected library collections from Jasna Gora library in Czestochowa. Journal of Visnyk Lvivskoho universytetu. Seriia knyhozn. bibliot. ta inf. tekhnol., 10, 63-69 [in English].

6. Maistrenko, A. \& Murashko, N. \& Khrystova, N. (2013). Metodyka otsiniuvannia fizychnoho stanu dokumentiv. Kyiv: Derzh. arkhiv. sluzhba Ukrainy, UNDIASD, 108 p. [in Ukrainian].

7. Manernova, O. V. (2010). Otsenka fizicheskogo sostoyaniya dokumentov. Tomsk: Regional'nyy tsentr restavratsii i konservatsii dokumentov Nauchnoy biblioteki Tomskogo gosudarstvennogo universiteta, 11 p. [in Russian].

8. Komarenko, E. I. (2003). Vliyanie osobennostey rezhima khraneniya na pamyatniki na bumazhnoy osnove. Journal of Materialy IV Mezhdunarodnoy nauch.-prakt. konf. 'Konservatsiya pamyatnikov kul'tury $v$ edinstve i mnogoobrazii', 28-31 [in Russian].

9. Vasil'eva, N. A. (2004). Osnovnye faktory sokhrannosti bibliotechnogo fonda. Journal of Materialy V Vseros. nauch.-prakt. konf. 'Sovremennye biblioteki v innovatsionnom obrazovatel'nom protsesse', 80-83 [in Russian].

10. Halaburda, A. (2015). Prychyny ruinuvannia paperu periodychnykh vydan druhoi polovyny XIX-pochatku XX st. i metody yikh konservatsii. Journal of Visnyk Lvivskoho universytetu. Seriia knyhozn. bibliot. ta inf. tekhnol., 10, 70-77 [in Ukrainian].

11. Mitrofanova, S. V. (2005). Uchet bibliotechnykh fondov. Moscow: Mezhregional'nyy tsentr bibliotechnogo sotrudnichestva, 272 p. [in Russian].

12. Orlov, A. I. (2002). Ekspertnye otsenki. Moscow: IVSTE, 31 p. [in Russian].

\section{Разработана классификация основных видов повреждения книжных изданий; проведена оценка состояния сохран- ности изданий фонда редких и ценных изданий научно- технической библиотеки «Киевского политехнического института имени Игоря Сикорского", выпущенных до 1850 года.}


Ключевые слова: фоксинги; угасание текста; повреждения бумаги; микологическое повреждение; тряпичная бумага; деструкция переплетного материала; изменение цвета.

The classification and systematization of major types of damage, which are inherent to particular parts of the books, was developed. This allows us to evaluate the safety of the paper and the block construction, book cover, text and illustrative information more thoroughly.

Keywords: foxings; the text senility; paper damage; mycological damage; rag paper; destruction of the binding material; color change.

Рецензент - В. М. Скиба, канд. техн. наук, доцент, КПІ ім. Ігоря Сікорського 